\title{
Practical problems associated with assessing the impact of outdoor smoking on outdoor air quality: an Edinburgh study
}

\author{
D. G. Snelson ${ }^{1}$, A. J. Geens ${ }^{1}$, H. Al-Madfai ${ }^{1}$ \& D. Hillier ${ }^{2}$ \\ ${ }^{1}$ Faculty of Advanced Technology, University of Glamorgan, UK \\ ${ }^{2}$ Faculty of Health, Sports \& Science, University of Glamorgan, UK
}

\begin{abstract}
Smoking in the United Kingdom is now banned in public places, subject to certain exempt situations. The last country to introduce the ban being England on the $1^{\text {st }}$ July 2007. People who smoke now congregate outside premises either sitting at tables or standing while smoking their cigarettes. Previous studies have concluded that measured outdoor pollutants are proportional to and correlated with smoker count and not with motor vehicle traffic. This paper reports on a case study conducted in Edinburgh and identifies lessons learnt from this and earlier studies. The authors having conducted this field work suggest that this is not necessarily the case and they have concluded that further work is required to establish a more robust methodology.
\end{abstract}

Keywords: smoking in public places, outdoor air quality, particulates, carbon monoxide.

\section{Introduction}

An experimental study was completed by Klepeis et al. [1] where outdoor communal areas were monitored, in the presence of smokers, to ascertain the levels of environmental tobacco smoke (ETS) in close proximity to smokers with burning cigarettes. For this study a number of similar venues in Edinburgh were used and further location types were added. In this study, levels of particulates (PM 2.5) and carbon monoxide (CO) have been recorded. Carbon dioxide $\left(\mathrm{CO}_{2}\right)$ Temperature $\left({ }^{\circ} \mathrm{C}\right)$, relative humidity $(\%)$, rain $(\mathrm{mm})$, sun $(\mathrm{hrs})$ and wind speed 
(knots) were also recorded as they may have an impact on the particulate concentration levels in the outdoor environment where ETS is being measured.

The background pollutant level concentrations are taken from the data supplied by the St. Leonards Air Quality monitoring station in the South of Edinburgh, part of the UK wide monitoring network managed by the Department for Environment, Food \& Rural Affairs (DEFRA). These background levels will be used to normalise locally monitored data in proximity to smokers. The particulates and gaseous pollutant threshold / limit values for air quality are set out in European Directives. In the United Kingdom the National Air Quality Standards [2] define levels which are believed to avoid significant risks to health. This paper compares the results from three Edinburgh venues, used to ascertain the levels of pollutant in close proximity to cigarette smokers, to those of the Klepeis et al. [1] study.

\section{Methodology}

The authors measured particulates (PM 2.5) and gaseous emission (CO) in the outdoor environment at three outdoor seating areas.

\subsection{On-site monitoring visits}

Three outdoor seating areas were measured (Last Drop Tavern, Beehive and The White Hart Inn) to investigate the levels of CO and PM 2.5 where smoking occurs in the outdoor environment. The sampling devices used in this study were

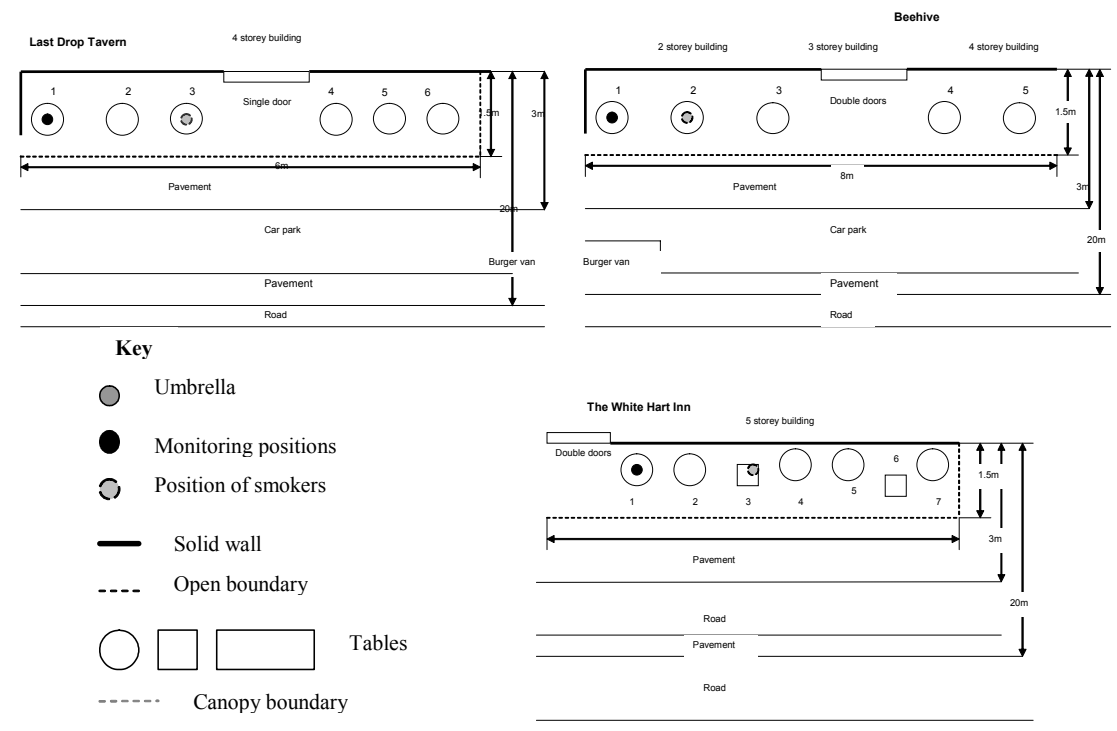

Figure 1: $\quad$ Schematic diagram of measurements venues and sites. 
the Dustrak Aerosol Monitor Model 8520 by TSI Inc, using the $2.5 \mu \mathrm{m}$ inlet conditioner and a flow rate of $1.7 \mathrm{l} / \mathrm{min}$, and the Q-Trak Plus IAQ Monitor Model 8554 by TSI Inc. A venue plan (Fig. 1), the characteristics (Table 1), the position of smokers and the duration of cigarette being smoked were recorded (Table 2). The sampling devices were located in the outdoor seating areas at a height approximating to the breathing zone, on a suitable table marked on the venue plan. Monitoring periods ranged from 60 minutes to 76 minutes.

Table 1: $\quad$ Characteristics of outdoor monitoring locations.

\begin{tabular}{|c|c|c|c|c|c|c|c|c|c|c|c|}
\hline Venues & $\begin{array}{l}\text { Monitoring } \\
\text { date }\end{array}$ & $\begin{array}{c}\text { Length of } \\
\text { monitoring } \\
\text { (mins) }\end{array}$ & $\begin{array}{l}\text { Monitoring } \\
\text { location }\end{array}$ & $\begin{array}{l}\text { Width } \\
(\mathrm{m})\end{array}$ & $\begin{array}{l}\text { Depth } \\
\text { (m) }\end{array}$ & $\begin{array}{l}\text { Building } \\
\text { height } \\
\text { (m) }\end{array}$ & $\begin{array}{c}\text { Distance } \\
\text { to } \\
\text { building } \\
\text { (m) }\end{array}$ & $\begin{array}{l}\text { Distance } \\
\text { to road } \\
(\mathrm{m})\end{array}$ & $\begin{array}{l}\text { Number } \\
\text { of Tables }\end{array}$ & $\begin{array}{l}\text { Seating } \\
\text { capacity }\end{array}$ & comments \\
\hline $\begin{array}{l}\text { Last Drop } \\
\text { Tavern }\end{array}$ & $\begin{array}{c}\text { Thursday } 20^{\text {th }} \\
\text { September } \\
2007\end{array}$ & 76 & Table 1 & 6 & 1.5 & 4 storeys & 0.5 & 20 & 6 & 22 & $\begin{array}{l}\text { Situated in the } \\
\text { Grassmarket Car } \\
\text { park opposite } \\
\text { seating area French } \\
\text { Connection food van } \\
8 \text { metres from } \\
\text { outdoor seating area }\end{array}$ \\
\hline Beehive & $\begin{array}{l}\text { Thursday } 3^{\text {rd }} \\
\text { August } 2007\end{array}$ & 60 & Table 1 & 8 & 1.5 & 3 storeys & 0.5 & 20 & 5 & 21 & $\begin{array}{l}\text { Situated in the } \\
\text { Grassmarket Car } \\
\text { park opposite } \\
\text { seating area French } \\
\text { Connection food van } \\
6 \text { metres from } \\
\text { outdoor seating area }\end{array}$ \\
\hline $\begin{array}{l}\text { The White Hart } \\
\text { Inn }\end{array}$ & $\begin{array}{c}\text { Thursday } 20^{\text {th }} \\
\text { September } \\
2007\end{array}$ & 63 & Table 1 & 8 & 1.5 & 5 storeys & 0.5 & 20 & 7 & 18 & $\begin{array}{l}\text { Situated in the } \\
\text { Grassmarket Car } \\
\text { park opposite } \\
\text { seating area French } \\
\text { Connection food van } \\
22 \text { metres from } \\
\text { outdoor seating area }\end{array}$ \\
\hline
\end{tabular}

\section{Background measurements}

Information on measurements recorded at the Edinburgh St. Leonards air quality monitoring station (Table 2) is outlined below.

\subsection{Carbon Dioxide}

Carbon Dioxide is a product of respiration and occurs naturally in the atmosphere. It is also worth noting that Carbon Dioxide is present in the Earth's atmosphere at approximately $375 \mathrm{ppm}$ [3] by volume and so, unlike other indicators, Carbon Dioxide will not tend towards zero when no pollution sources are active.

\subsection{Temperature}

The daily and seasonal solar cycles will essentially control the temperature profile of the lower atmosphere [4]. During daylight hours, the temperature in the lower atmosphere typically decreases with height. As evening approaches, 
the suns heating effect decreases and the earth's surface loses heat to the atmosphere. As the earth surface and the lower levels of the atmosphere cool the vertical temperature profile of the atmosphere is now in reverse of the daytime situation [4]. The increasing temperature with height is called a temperature inversion. The region of air that extends from the earth's surface to the base of the temperature inversion is referred to as the mixing layer [4]. The lower the depth of the mixing layer the less volume that is available to mix the pollutant with fresh air. The mixing layer is important in cities where high volumes of pollutants are released near ground level [4].

\subsection{Wind speed}

Changes in pressure and temperature in the atmosphere cause the movement of air. The speed of the wind will determine how long it takes for air pollutants to travel from their source to the measuring device. Also at higher wind speeds the pollutants released at or near ground level will disperse more rapidly into the surrounding atmosphere. Pollutants released when the wind speeds are low at or near ground level will disperse at a lower rate [5] for example vehicle exhaust. Wind speed data was supplied by defra from Edinburgh St. Leonards air quality monitoring site (see Table 2). Table 2 refers to the time period when the outdoor smoking measurements were recorded by the authors.

Table 2: $\quad$ Edinburgh air quality data for the $20^{\text {th }}$ September 2007.

\begin{tabular}{ccccccccc}
\hline Time & \multicolumn{7}{c}{ 20/09/2007 } \\
\cline { 2 - 8 } & $\begin{array}{c}\mathrm{PM}_{10} \\
\left(\mathrm{mg} / \mathrm{m}^{3}\right)\end{array}$ & $\begin{array}{c}\mathrm{CO} \\
\left(\mathrm{mg} / \mathrm{m}^{3}\right)\end{array}$ & $\begin{array}{c}\text { Temp } \\
\left({ }^{\circ} \mathrm{C}\right)\end{array}$ & $\begin{array}{c}\text { Rel Humidity } \\
(\%)\end{array}$ & $\begin{array}{c}\text { Rain } \\
(\mathrm{mm})\end{array}$ & $\begin{array}{c}\text { Sun } \\
(\mathrm{hrs})\end{array}$ & $\begin{array}{c}\text { Wind - Mean } \\
\text { Speed (knots })\end{array}$ & $\begin{array}{c}\text { Wind - } \\
\text { Mean Dir }\end{array}$ \\
\hline $11: 00$ & 7 & 0.2 & 13.7 & 72.1 & 0.0 & 0.0 & 13 & 240 \\
$12: 00$ & 10 & 0.2 & 13.8 & 72.1 & 0.0 & 0.0 & 13 & 240 \\
$13: 00$ & 12 & 0.2 & 13.8 & 65.8 & 0.0 & 0.3 & 15 & 240 \\
$14: 00$ & 12 & - & 15.6 & 61.9 & 0.0 & 0.9 & 17 & 240 \\
$15: 00$ & 14 & 0.2 & 14.9 & 62.9 & 0.0 & 0.8 & 19 & 250 \\
\hline
\end{tabular}

\section{Smokers}

The data outlined below relates to outdoor smoking activities at venues (Table 1 and Fig. 1) where CO and PM 2.5 levels were measured.

\subsection{Data on smokers}

The approximate times when a cigarette was lit and extinguished, the position of the smoker and the distance to the monitoring equipment were recorded (Table 3). This will give an indication of the distance at which the cigarette smoke can be detected by the monitoring equipment. 
Table 3: Details of smoking activities.

\begin{tabular}{|c|c|c|c|c|c|c|c|c|}
\hline Venues & Monitoring date & $\begin{array}{l}\text { Length of } \\
\text { monitoring } \\
\text { (mins) }\end{array}$ & $\begin{array}{l}\text { Monitoring } \\
\text { location }\end{array}$ & $\begin{array}{l}\text { Smokers } \\
\text { table }\end{array}$ & $\begin{array}{c}\text { Number of } \\
\text { smokers }\end{array}$ & $\begin{array}{c}\text { Number of } \\
\text { cigarettes } \\
\text { smoked }\end{array}$ & $\begin{array}{l}\text { Time and } \\
\text { duration of } \\
\text { smoking } \\
\text { activity }\end{array}$ & $\begin{array}{c}\text { Distance } \\
\text { from } \\
\text { monitoring } \\
\text { location }\end{array}$ \\
\hline $\begin{array}{l}\text { Last Drop } \\
\text { Tavern }\end{array}$ & $\begin{array}{l}\text { Thursday } 20^{\text {th }} \\
\text { September } 2007\end{array}$ & 76 & Table 1 & Table 3 & One & One & $13.05-13.12$ & $2.5 \mathrm{~m}$ \\
\hline Beehive & $\begin{array}{l}\text { Thursday } 3^{\text {rd }} \\
\text { August } 2007\end{array}$ & 60 & Table 1 & Table 2 & Three & Three & $16.41-16.47$ & $1 \mathrm{~m}$ \\
\hline $\begin{array}{l}\text { The White } \\
\text { Hart Inn }\end{array}$ & $\begin{array}{l}\text { Thursday } 20^{\text {th }} \\
\text { September } 2007\end{array}$ & 63 & Table 1 & Table 3 & Two & Two & $13.55-14.02$ & $1.5 \mathrm{~m}$ \\
\hline
\end{tabular}
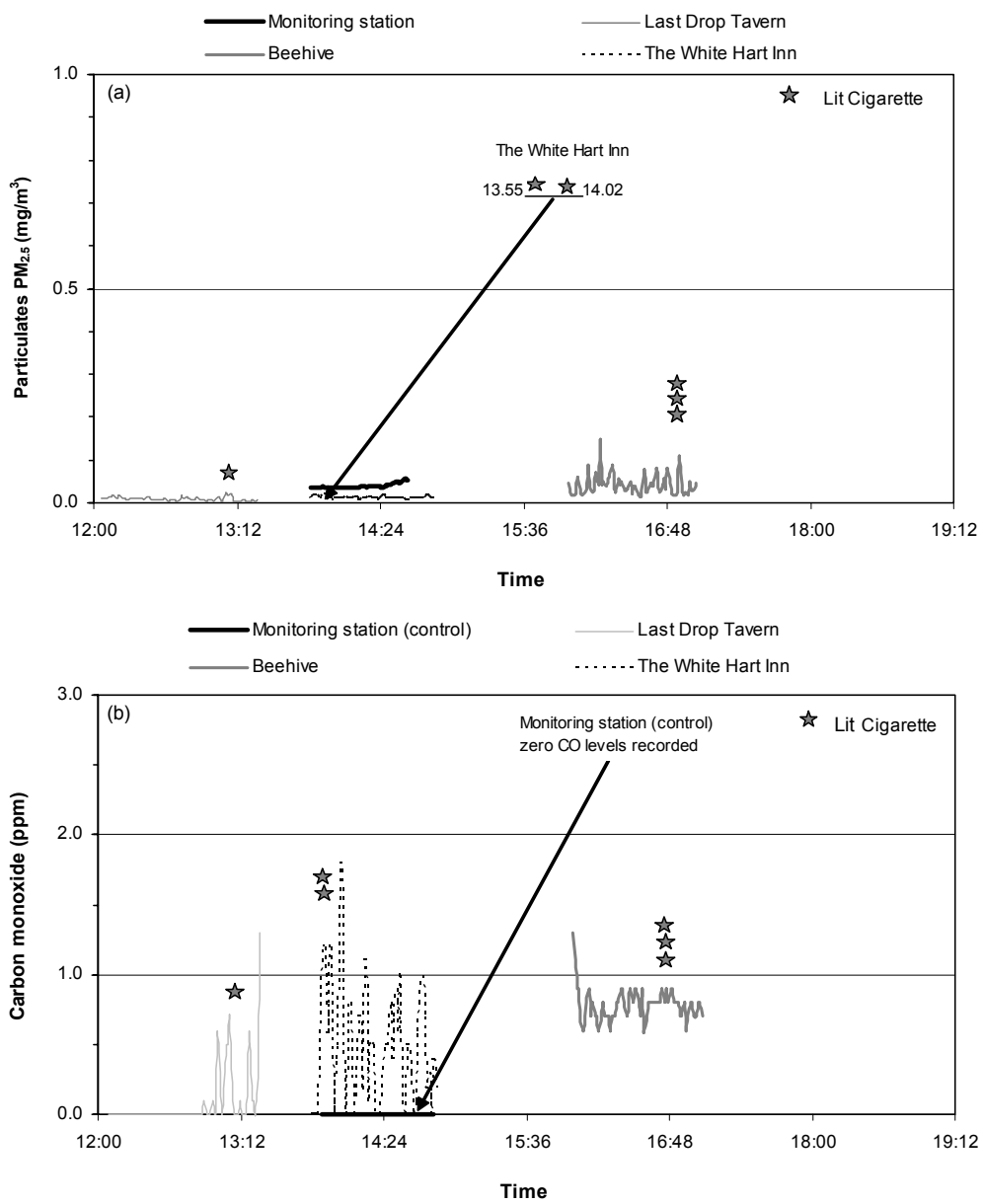

Figure 2: $\quad$ Graphs of CO and PM 2.5 levels measured at all sites. 


\subsection{Concentration levels of $\mathrm{CO}$ and PM 2.5}

Figure 2 shows the levels of CO and PM 2.5 recorded at all sites. The maximum concentration of $\mathrm{CO}$ recorded at the individual venues is shown in Figure 3. The monitoring station (St. Leonards) gives the background pollutant level concentrations. Higher levels of $\mathrm{CO}$ were recorded at a bus stop from traffic exhaust fumes than from the cigarette smoke at the three venues. This was probably due to the maintainace work being carried out on the road causing the stagnation of the traffic increasing the concentration of the $\mathrm{CO}$; this is further discussed in section 5 .

\subsection{Distance to the smoker}

As the cigarette smoke plume is released into the atmosphere the concentration will be diluted by the surrounding air. The distance at which the CO and PM 2.5 can be detected is difficult to establish. The authors have conducted two tests; a walk by test one metre from a lit cigarette and another sitting opposite a smoker at a table, but these results are not presented in this paper as they are inconclusive. The weather conditions at the time of monitoring will have a bearing on the distance from the source that the CO and PM 2.5 can be detected by the monitoring equipment.

\section{Discussion}

The investigating team has found that whilst the background levels of a wide range of airborne contaminants can be successfully monitored, as demonstrated

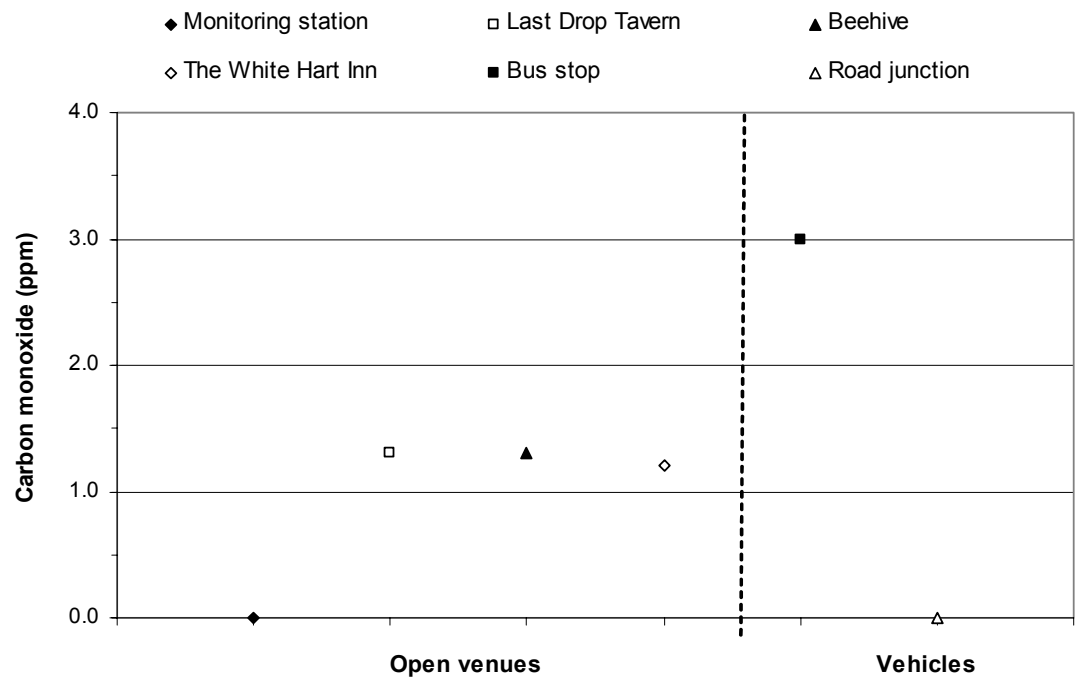

Figure 3: Graphs of maximum CO levels measured at all sites. 
by the defra monitoring stations, it is very difficult to reliably monitor what is happening at a local level (Fig. 3). For example, the emissions from a bus exhaust can be observed to decay rapidly with distance and yet carbon monoxide can be detected as a smoker walks by. Although sources are very variable, (size/speed of vehicle, brand of cigarette), the rate of carbon monoxide production $(1 / \mathrm{s})$ from a vehicle is of the order of ten times the rate from a cigarette. The levels that are monitored are very dependent on distance. Furthermore, in assessing health risk, duration is as significant as level. Weather factors as well as degree of enclosure by adjacent structures are further variable factors. Some theoretical modelling (Gaussian plume) of the effect of the wind speed and direction would be useful in determining some of the critical factors, before moving to further field tests.

\section{Conclusions}

With the number of variables present and the subjectivity of the monitoring methods, studies such as the one reported by Klepeis et al. [1] and repeated in Edinburgh by Snelson et al, can only provide broad observations and perhaps identify areas of concern that may justify a more considered and lengthy treatment. Much further work is required to establish a robust methodology for this type of investigation as well as to establish the important or significant criteria before any sound conclusions can be drawn.

\section{Acknowledgement}

This study was commissioned by the Scottish Licensed Trade Association with funding support from the UK Tobacco Manufacturers' Association.

\section{Reference}

[1] Klepeis, N., Ott, W. \& Switzer P., Real-Time Measurement of Outdoor Tobacco Smoke Particles, Journal of Air \& Waste Management Association, 57, (5), pp. 522-534, 2007.

[2] The Air Quality Strategy for England, Scotland, Wales and Northern Ireland. Department for Environment Food and Rural Affairs in Partnership with the Scottish Executive, Welsh Assembly Government and Department of the Environment Northern Ireland, Volume 2, The Stationary Office 2007, http://www.defra.gov.uk/environment/airquality/strategy/pdf/airqualitystrategy-vol2.pdf

[3] Whorf, T.P. \& Keeling, C.D., Atmospheric $\mathrm{CO}_{2}$ records from sites in the SIO air sampling network, 2005.

[4] Temperature, 2006, http://casadata.org/whatis/temperature.asp

[5] Wind, 2006, http://casadata.org/whatis/wind.asp 